\title{
EU12: Državne potpore prije i poslije pristupanja Europskoj uniji
}

IVANA JOVIĆ* Privredna banka Zagreb

\section{UVOD I SAŽETAK}

Područje državnih potpora jedno je od rijetkih - ako ne i jedinih područja u kojima se učinci pristupanja neke zemlje Europskoj uniji (EU) mogu jasno i nedvojbeno kvantificirati. Podaci o kretanju državnih potpora u zemljama EUı2 ${ }^{\mathrm{I}}$ koje su EU-u pristupile 2004. odnosno 2007. jasno ukazuju na te učinke i daju dobru podlogu za analizu i predviđanje kako će se proces pridruživanja odraziti na državne potpore u Hrvatskoj.

Glavni zaključci analize kretanja državnih potpora u EUI2 jesu:

- Proces pristupanja EU-u bio je nesumnjivo glavni pokretač reforme državnih potpora u EUI2.

- Doveo je do značajnih promjena u politikama državnih potpora zemalja EUI2, ne samo u pogledu njihove razine, strukture i instrumenata dodjele već i do promjene poimanja ciljeva potpora odnosno njihove kontrole.

- Iako nakon pristupanja primjenjuju zajednička pravila Europske komisije o držaunim potporama, zemlje EUı2 i dalje vode heterogene politike državnih potpora, premda daleko manje nego prije pristupanja EU-u.

\footnotetext{
* Autorica je pomoćnik izvršnog direktora u Uredu za ekonomska istraživanja i strateško planiranje Privredne banke Zagreb (PBZ). Tvrdnje u tekstu isključivo su osobni stavovi autorice te ni u kojem slučaju ne izražavaju stajalište ili mišljenje institucije u kojoj je zaposlena.

I EUı2 su nove članice EU-a (Bugarska, Češka, Estonija, Cipar, Latvija, Litva, Mađarska, Malta, Poljska, Rumunjska, Slovenija i Slovačka), a EUi5 su stare članice (Austrija, Belgija, Danska, Finska, Francuska, Njemačka, Grčka, Irska, Italija, Luksemburg, Nizozemska, Portugal, Španjolska, Švedska, Velika Britanija).
}

- Iskustvo EUı2 zemalja je proces kroz koji RH djelomice već prolazi u posljednjih nekoliko godina, no prema nalazima analize Kesner-Škreb (2OI2) glavnina prilagodbe će se dogoditi neposredno nakon pristupanja EU-u, a to će dodatno pojačati i reforma sustava državnih potpora koju Europska komisija trenutno priprema, a koja bi na snagu trebala stupiti krajem 2013.

\section{VELIČINA I STRUKTURA DRŽAVNIH POTPORA \\ U NOVIM ĞLANIGAMA EUROPSKE UNIJE}

Usporedi li se razina državnih potpora u EUı2 nekoliko godina prije proširenja, odnosno tijekom 20oo. (EUIo) i 2002. (Bugarska i Rumunjska), mogu se uočiti velika odstupanja u odnosu na zemlje EUi5. Razina državnih potpora u EUı2 (I,2\% BDP-a) prosječno je uglavnom bila dvostruko veća od razine EUi5 (o,6\% BDP-a).

Posljedica je to socijalističkog sustava upravljanja u kojem su državne potpore bile ključan element gospodarske politike. Reforma sustava državnih potpora u zemljama Središnje i Istočne Europe započela je tranzicijom prema tržišnoj ekonomiji ranih I990-ih, odnosno liberalizacijom dotada administrativno određivanih cijena što je dovelo do ukidanja subvencija. Međutim, značajne promjene koje su uslijedile prelaskom na tržišno gospodarstvo imale su negativan učinak na neke sektore (ugljen, čelik, energetika, prerađivačka industrija, poljoprivreda) što je potaknulo različite vidove državnih intervencija odnosno potpora, osobito poduzećima u još uvijek dominantnom 


\section{Grafikon I.}

Udio državnih potpora (bez željeznica) u BDP-u 2000. (2002.) u EUI5 i EUI2 (u \%)

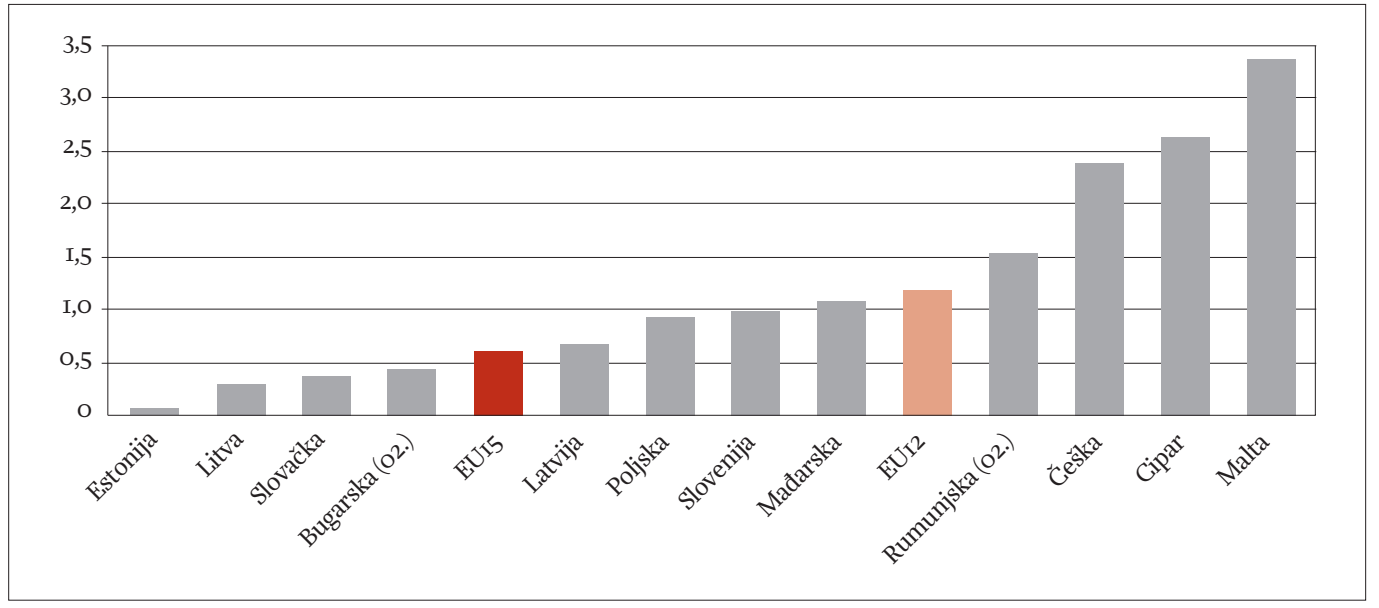

Izvor: European Commission (2012)

državnom vlasništvu. Novi korak u smanjenju potpora učinjen je sredinom I99o-ih, stupanjem na snagu Ugovora o pristupanju EU/EZ ${ }^{2}$ i obvezivanjem EUı2 zemalja na prihvaćanje legislative EU-a. Dodatni poticaj reformi sustava državnih potpora došao je i nastojanjem zemalja da ispune Kopenhaške kriterije pristupanja koji se odnose na ostvarenje tržišne ekonomije, punu liberalizaciju cijena te sposobnost gospodarskih subjekata da se nose s konkurentskim snagama jedinstvenog tržišta EU-a (Mulas-Granados, Koranchelian i Segura-Ubiergo, 2008). S obzirom da državne potpore imaju ključnu ulogu u stvaranju funk- cionirajuće tržišne ekonomije, efikasna primjena i provođenje politike državnih potpora bila je neophodna komponenta procesa pridruživanja.

Proces proširenja EU-a znatno je utjecao na kretanje državnih potpora u EUı2 zemljama u smjeru smanjenja njihove ukupne razine, ali i promjene vrsta danih potpora.

Grafikon 2 zorno prikazuje stupanj smanjenja udjela $\mathrm{u}$ BDP-u do I,9 strukturna poena do kojeg je došlo u zemljama EUı2. Najveće smanjenje bilježi Češka, dok je primje-

\section{Grafikon 2.}

Državne potpore (bez poljoprivrede i prometa ${ }^{3}$, udio u BDP-u) za EUI2 prije i poslije pristupanja EU-u

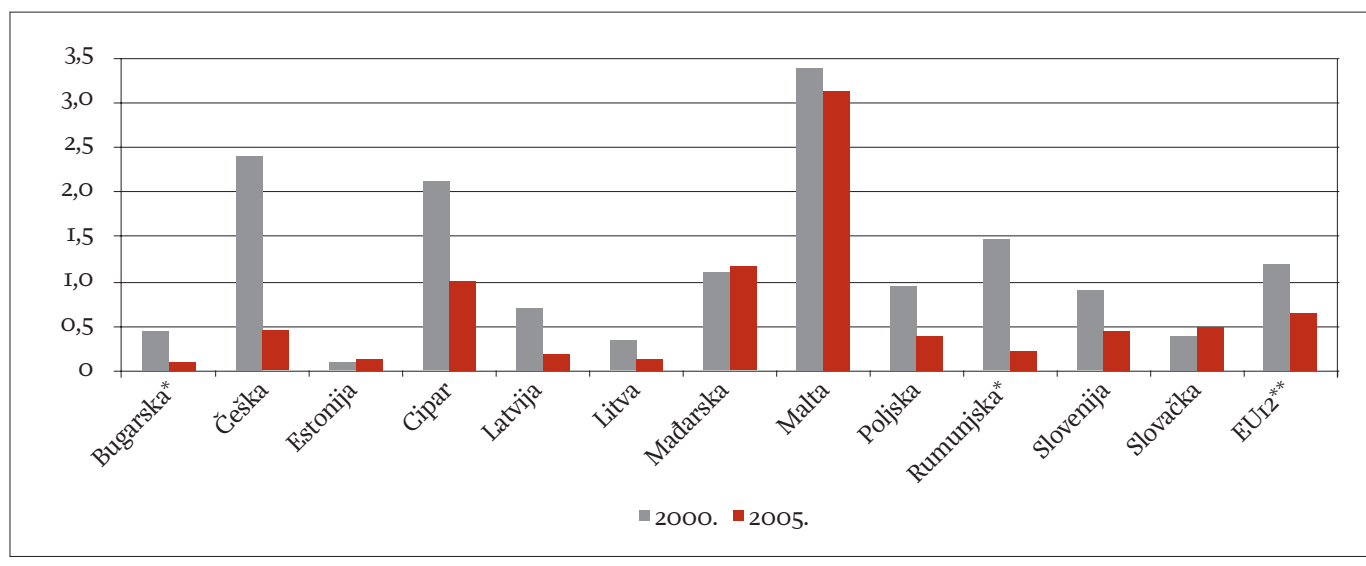

* Bugarska i Rumunjska 2002. i 2007.

** neponderirani prosjek

Izvor: European Commission (2012); izračun autorice

2 The Europe Agreements stupili su na snagu I994. u Mađarskoj i Poljskoj; I995. u Bugarskoj, Češkoj, Rumunjskoj i Slovačkoj; I998. u Estoniji, Litvi i Latviji i i999. u Sloveniji.
3 Potpore za poljoprivredu i ribarstvo te za promet u nadležnosti su DG Agriculture i DG Transport, stoga ih DG Competition ne obuhvaća u detaljnim prikazima razine potpora u EU-u. 
rice u Mađarskoj i Slovačkoj došlo do blagog rasta no znatno izmijenjene strukture o čemu će više riječi biti u nastavku teksta.

Međutim, bitno je napomenuti da se smanjenje razine državnih potpora nije kretalo linearno od 200o. nadalje, već je neposredno prije pristupanja, dakle 2002. i 2003. došlo do povećanja potpora na razinu gotovo triput veću od prosjeka EUi5 (vidi grafikon 3). Posebno su 2002. povećane potpore u Češkoj zbog krize bankarskog sektora te 2003. u Poljskoj zbog restrukturiranja ugljenokopa. Neke su zemlje, dakle, iskoristile priliku i odobrile nezanemarive državne potpore posljednji put prije no što je kontrola prešla u ruke Europske komisije. Taj potez zapravo pokazuje da su razumjele EU pravila o državnim potporama i nadolazeća ograničenja pod kontrolom Europske komisije. Nakon pristupanja, razina potpora $\mathrm{u}$ EUı2 dramatično se smanjuje i prije krize 2008. gotovo da nema razlike između prosjeka EUı2 i EUı5.

Osim same ukupne razine potpora, pristupanje je za većinu EUı2 zemalja značilo i promjenu u strukturi potpora, tj. došlo je do smanjenja udjela sektorskih i povećanja udjela horizontalnih potpora, u skladu s pravilima EU-a. Naime, EU se zalaže za “manje i bolje državne potpore”, tj. one usmjerene prema horizontalnim ciljevima koje najmanje narušavaju konkurenciju, a uglavnom se odnose na istraživanje i razvoj, mala i srednja poduzeća, zaštitu okoliša te obrazovanje i usavršavanje.

\section{Grafikon 3.}

Kretanje državnih potpora (bez prometa i poljoprivrede, u \% BDP-a) u odabranim EUı2 zemljama

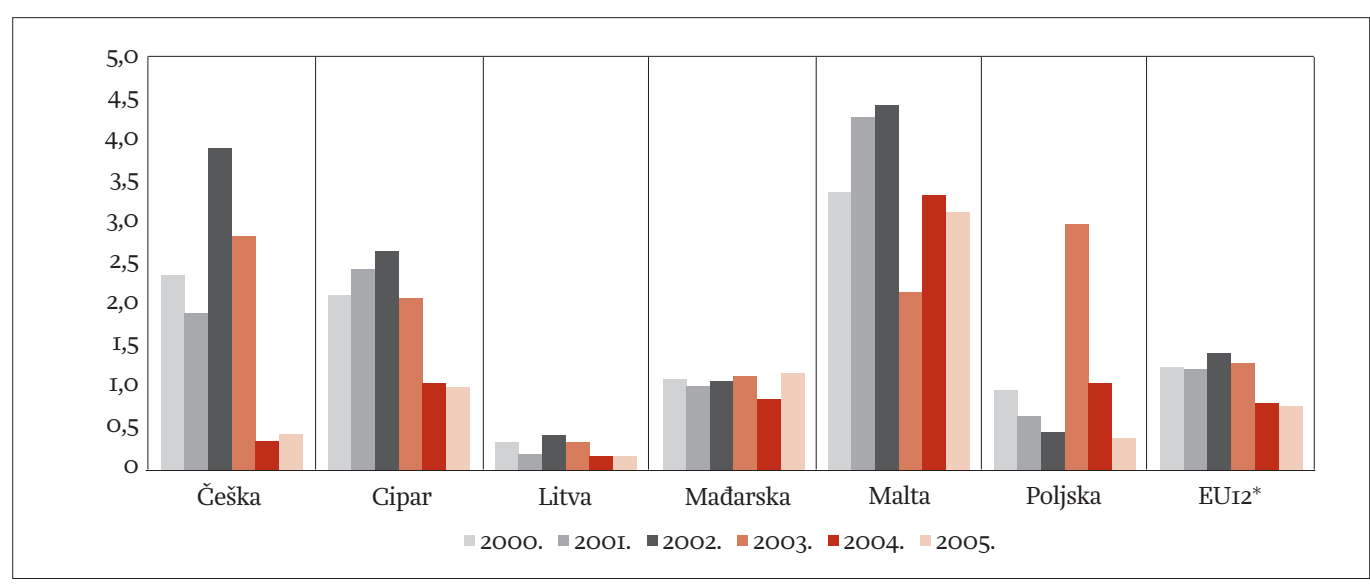

* neponderirani prosjek

Izvor: European Commission (2012); izračun autorice

\section{Grafikon 4.}

Struktura državnih potpora (bez prometa i poljoprivrede) 2000. i 2005. (u \%)

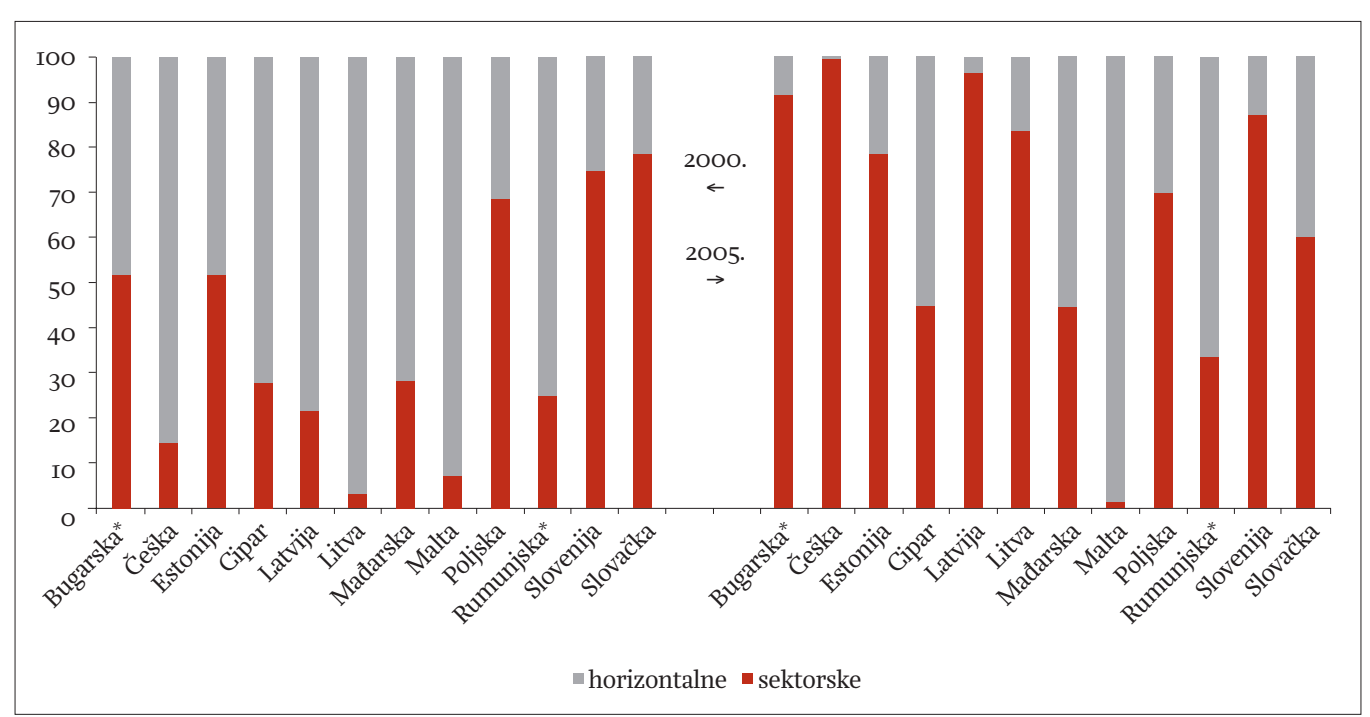

* Bugarska i Rumunjska 2002. i 2007.

Izvor: European Commission (2012); izračun autorice 
Struktura potpora, kao što se vidi u grafikonu 4, drastično se promijenila $\mathrm{u}$ korist horizontalnih potpora čiji se udio u nekim zemljama, poput primjerice Češke, povećao sa I4,4 na 99,6\%. Iznimka je Slovačka koja bilježi povećanje udjela sektorskih potpora i smanjenje udjela horizontalnih potpora u promatranom razdoblju, no horizontalne potpore i dalje dominiraju udjelom. Slično kao i kod ukupne razine potpora, rast udjela horizontalnih potpora nije tekao linearno, već je njihov udio 2003. čak i smanjen, da bi tek nakon pristupanja došlo do rasta udjela (Blauberger, 2007). No, takvo kretanje nije čudno s obzirom da je visoka "potražnja" za sektorskim potporama u EUı2 zemljama vezana uz proces ekonomske tranzicije, pa je to bio važan instrument $u$ procesu restrukturiranja i privatizacije državnih poduzeća kojim su se smanjile negativne socijalne posljedice tih procesa.

\section{POLITIKA PREMA POTPORAMA}

Reforma sustava državnih potpora odvijala se tijekom predpristupnih godina različito između zemalja EUı2, ovisno o namjeni potpora. Tako je smanjenje opće razine u nekim zemljama išlo brže nego u drugima, npr. neke zemlje poput Slovačke i Poljske suočile su se s otporom pri reformi poljoprivrednih potpora dok su reforme $u$ drugim sektorima išle daleko lakše, pa su sukladno tome i konačni rezultati reformi različiti.

Iako se promjene u politikama državnih potpora uglavnom mogu jasno vezati uz (očekivani) utjecaj procesa pristupanja EU-u, (nakon pristupanja i kontroli od strane Europske komisije), ne smije se zanemariti niti komponenta domaćeg utjecaja na ovo područje.

\section{Grafikon 5.}

Struktura potpora (industriji i uslugama) prema instrumentima (u \%)

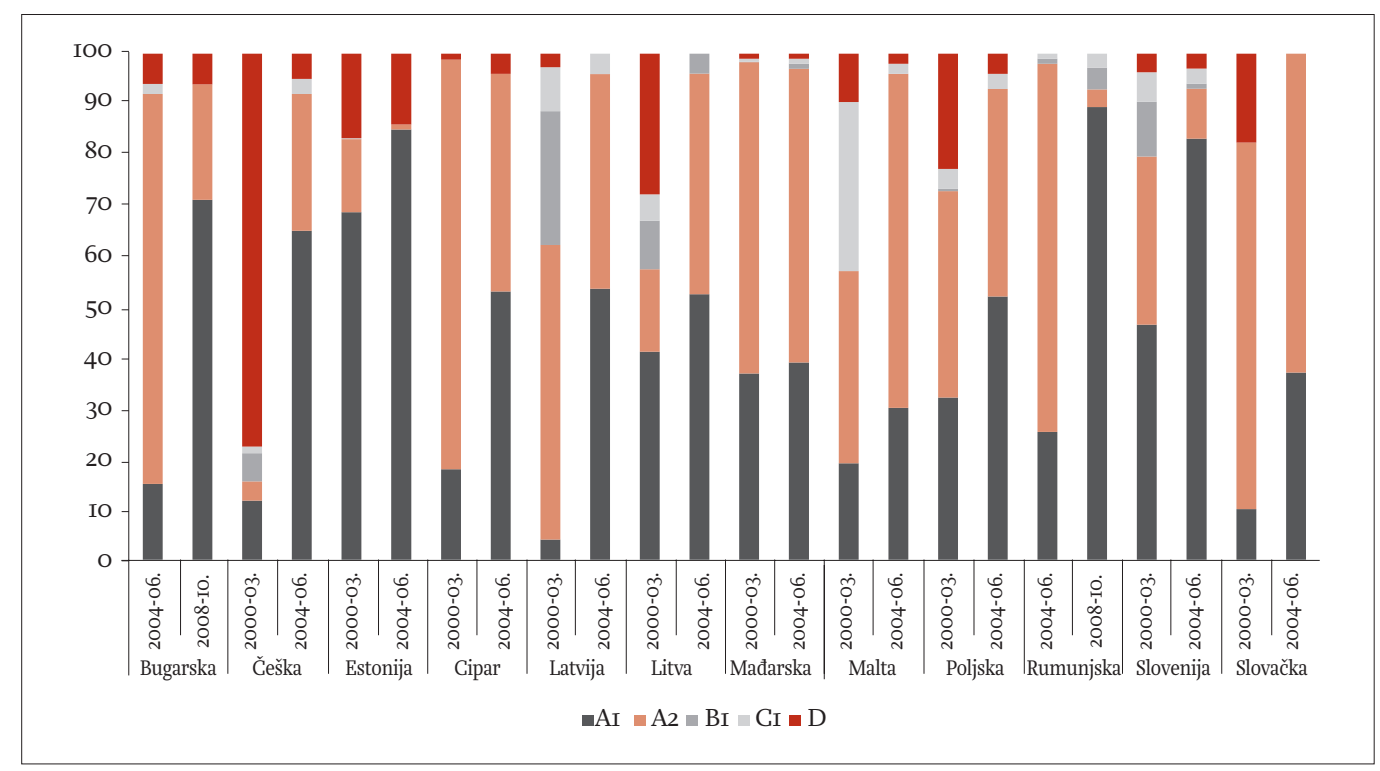

Izvor: European Commission (2012); izračun autorice

Državne potpore u EU-u najvećim se dijelom dodjeljuju putem izravnih subvencija koje se smatraju transparentnijim instrumentom od primjerice poreznih dugova. Stoga se promjena $u$ strukturi vidi i kod instrumenata ${ }^{4}$ dodjele državnih potpora. Promatraju li se dva razdoblja, neposredno prije i poslije pristupanja EU-u, evidentna je promjena $\mathrm{u}$ korist subvencija čiji je udjel postao dominantan u strukturi (vidi grafikon 5). Uz subvencije, zemlje u većoj mjeri koriste i porezna oslobođenja i izuzeća, pa se tako npr. dvije trećine potpora u Slovačkoj dodjeljuje upravo tim instrumentom. Ostali instrumenti - poput udjela u vlasničkom kapitalu, povoljnih zajmovai državnih jamstava - svoj su udio u potporama smanjili drastično.
Mulas-Granados, Koranchelian i Segura-Ubiergo (2008) tvrde da stupanj eksternih uvjeta objašnjava većinu različitosti u reformama ovisno o vrstama potpora. Visok stupanj vanjske uvjetovanosti karakterizira sva područja u kojima je EU nametnuo jaki pritisak na EUı2 zemlje u pogledu usklađenosti s pravnom stečevinom. U područjima gdje je uvjetovanost od strane EU-a bila snažnija, domaće je ograničenje (opozicija reformama) imalo manju ulogu i razlike u reformama među zemljama bile su manje. Domaća se ograničenja mogu odnositi na opoziciju

4 Instrumenti dodjele potpora su AI subvencije, A2 porezna izuzeća i oslobođenja, BI udjeli u vlasničkom kapitalu, GI povoljniji zajmovi i D državna jamstva. 
lobija, sindikata, manjak koordinacije vlada i regulatornih agencija, utjecaj političkih stranaka, itd.

Područje državnih potpora snažno je eksterno uvjetovano s obzirom da se smatra osnovnom komponentom zajedničkog tržišta i tržišne ekonomije.

Razlike $\mathrm{u}$ reformama pojedinih vrsta potpora između zemalja tumače domaća ograničenja, pa kako eksterna uvjetovanost slabi tako u reformskim procesima raste utjecaj domaćih ograničenja. Prema Mulas-Granados, Koranchelian i Segura-Ubiergo (2008) uglavnom se mogu odrediti četiri tipa domaćih ograničenja koja su utjecala na reforme EUı2 zemljama: (I) nepovoljna početna gospodarska situacija (nizak gospodarski rast, visoka nezaposlenost ili inflacija otežava provođenje reformi); (2) izborna ograničenja i snaga domaćih lobija (provedbu onemogućavaju relativno snažni lobiji sektora u kojima se reforme trebaju provesti); (3) rascjepkani/decentralizirani sustav donošenja odluka stvaraju probleme pri koordinaciji i nadležnosti i kompliciraju reforme i (4) slabi neovisni regulatori (reforma potpora bila je slabija u zemljama u kojima je regulator imao malu moć i nije mogao provoditi promjene cijena, npr. u energetskom sektoru).

Mulas-Granados, Koranchelian i Segura-Ubiergo (2008) objašnjavaju da se, u većini slučajeva, rezultat reformi potpora može objasniti kombinacijom eksternih uvjetovanosti i domaćih političkih ograničenja.

\section{Tablica I.}

Primjeri reformi državnih potpora u zemljama EUı2

\begin{tabular}{|c|c|c|}
\hline \multirow{2}{*}{$\begin{array}{l}\text { Domaća } \\
\text { ograničenja }\end{array}$} & \multicolumn{2}{|c|}{ Eksterna uvjetovanost } \\
\hline & visoka & niska \\
\hline \multirow{2}{*}{ visoka } & $\begin{array}{l}\text { reforma državnih } \\
\text { potpora u Cipru }\end{array}$ & $\begin{array}{l}\text { reforma energetskih } \\
\text { subvencija u Mađarskoj }\end{array}$ \\
\hline & $\begin{array}{l}\text { reforma državnih } \\
\text { potpora na Malti }\end{array}$ & $\begin{array}{l}\text { reforma prometnih } \\
\text { subvencija u Češkoj }\end{array}$ \\
\hline \multirow{2}{*}{ niska } & $\begin{array}{l}\text { reforma poljoprivrednih } \\
\text { subvencija u Slovačkoj }\end{array}$ & $\begin{array}{l}\text { reforma energetskih } \\
\text { subvencija u Rumunjskoj }\end{array}$ \\
\hline & $\begin{array}{l}\text { reforma poljoprivrednih } \\
\text { subvencija u u Poljskoj }\end{array}$ & $\begin{array}{l}\text { reforma prometnih } \\
\text { subvencija u Estoniji }\end{array}$ \\
\hline
\end{tabular}

Izvor: Mulas-Granados, Koranchelian i Segura-Ubiergo (2008)

Situacija s visokim stupnjem eksterne uvjetovanosti i domaćeg ograničenja rezultira uspješnim provođenjem reforme, ali zemlje s takvom situacijom često dogovaraju neke prijelazne mjere pri pristupanju EU-u. Kada je stupanj eksterne uvjetovanosti visok, a snaga domaćih ograničenja mala, reforme se provode bez prijelaznih mjera. Nizak stupanj eksternih uvjetovanosti i visoka snaga domaćih ograničenja dovodi do limitiranih i nepotpunih reformi. Nizak stupanj eksternih uvjetovanosti i slaba snaga domaćih ograničenja rezultira reformama samo u slučaju prijašnjih neuspjeha i snažnog domaćeg konsenzusa, te odlučnosti da se reforma provede.

\section{Reforma energetskih subvencija u Mađarskoj i prometnih u Češkoj}

Reforma energetskih subvencija u Mađarskoj i prometnih u Češkoj najbolji su primjer reformi s niskom eksternom uvjetovanošću i visokim domaćim ograničenjima. Vlade su $\mathrm{u}$ obje zemlje nastojale ispuniti minimum EU zahtjeva $\mathrm{u}$ smislu otvaranja tržišta EU kompanijama, ali je političko uplitanje blokiralo reforme. Reforme u Mađarskoj su usporene zbog neslaganja vlade i neovisnog regulatora, dok je opseg reforme u Češkoj smanjen zbog sukoba vlade, prometne kompanije i sindikata.

Imajući na umu spomenuti koncept zanimljivo je pogledati rezultate pregovora EUı2 zemalja i područja na kojima su dobile prijelazne mjere.

U samom procesu pristupnih pregovora šest od deset zemalja ispregovaralo je prijelazne mjere za reformu državnih potpora, a sve su prihvatile i trogodišnje prijelazno razdoblje prije pristupanja sustavu Zajedničke poljoprivredne politike.

Proces pristupanja započeo je i998., odredivši uvjete pod kojima je pojedina zemlja pristupila EU-u. Pristupnim su pregovorima određeni uvjeti pod kojima je zemlja kandidat prihvatila, primijenila i provela pravnu stečevinu, odnosno detaljni zakoni i pravila usvojena na bazi Ugovora o osnivanju Europske zajednice, i odobravanje prijelaznih mjera ograničenih obuhvatom i trajanjem. U praksi, svaka od EUı2 zemalja osnovala je državno tijelo za nadgledanje potpora koje je pratilo dodjelu javnih sredstava kako bi odredilo predstavlja li ono ili ne državnu potporu kako je definirano člankom 87. Ugovora o osnivanju EZ-a te je li to kompatibilno sa zajedničkim tržištem. U slučaju da identificirane državne potpore nisu u skladu s EU pravnom stečevinom, zemlje su ih trebale ili prilagoditi standardima Unije ili ih ukinuti, odnosno postepeno smanjivati. Do prvih je konkretnih pomaka na području državnih potpora došlo tek tijekom 200o/oI., a pregovori su završeni u prosincu 2002.

Tijekom pregovora se pokazalo da su dvije vrste potpora osobito problematične. Prvo, fiskalne potpore koje nisu u skladu s člankom 87. Ugovora, a odnose se na razne oblike poreznih olakšica što se dodjeljuju radi privlačenja stranih investitora. Drugo, spašavanje poduzeća u teškoćama primjenom instrumenata kao što su porezni dug ili jamstva. Pregovori o prijelaznim razdobljima vodili su se prema osnovnom načelu da moraju biti ograničeni s obzirom na vrijeme i područje primjene. Estonija, Litva, Latvija i Slovenija nisu tražile prijelazne mjere. 
Tablica 2.

Dogovorene prijelazne mjere i posljedice

Zemlja

Dogovoreno

Posljedice

Cipar Ukidanje neodgovarajućih fiskalnih potpora do kraja 2005.

Razina državnih potpora pala je s I,6\% BDP-a (2004.) na o,6\% BDP-a (2006.).

Češka Završetak restrukturiranja industrije čelika do 3I. I2. 2006.

Drastično smanjenje udjela sektorskih potpora s $88 \%$ (2003.) na $0,2 \%$ (2007.).

Postupno ukidanje neodgovarajućih fiskalnih potpora malim i srednjim poduzećima do kraja 2 OII.

Zamjena neodgovarajućih fiskalnih potpora velikim poduzećima regionalnom potporom za ulaganje; potpora će se ograničiti na najviše 75 ili 50\% prihvatljivih troškova ulaganja, ovisno Mađarska o datumu početka investiranja; u sektoru proizvodnje cestovnih vozila potpora se dodatno ograničava, te se određuje na razini od 30 ili 20\% prihvatljivih troškova ulaganja.

Postupno ukidanje neodgovarajućih fiskalnih potpora off-shore poduzećima do kraja 2005. Postupno ukidanje neodgovarajućih fiskalnih potpora koje dodjeljuju lokalne vlasti do kraja 2007.

Postupno ukidanje neodgovarajućih fiskalnih potpora malim i srednjim poduzećima do kraja 2OII.

Zamjena neodgovarajućih fiskalnih potpora velikim poduzećima regionalnom potporom za ulaganje; potpora će se ograničiti na najviše 75 ili 50\% prihvatljivih troškova ulaganja, ovisno Malta o datumu dobivanja poreznog izuzeća.

Potpore restrukturiranju brodogradnje tijekom razdoblja restrukturiranja koje traje do kraja 2008.

Postupno ukidanje operativne potpore iz Zakona o poticanju poslovanja (Business Promotion Act) do kraja 2008.

Postupno ukidanje neodgovarajućih fiskalnih potpora malim poduzećima do kraja $20 I I$. Postupno ukidanje neodgovarajućih fiskalnih potpora srednjim poduzećima do kraja 2010. Zamjena neodgovarajućih fiskalnih potpora velikim poduzećima regionalnom potporom za ulaganje; potpora će se ograničiti na najviše 75 ili 50\% prihvatljivih troškova ulaganja, ovisno Poljska o datumu dobivanja dozvole; u sektoru proizvodnje motornih vozila potpora se dodatno ograničava, te se određuje na razini od 30\% prihvatljivih troškova ulaganja.

Na području državnih potpora za zaštitu okoliša dopuštaju se standardne investicije za koje je u poglavlju o okolišu dogovoreno prijelazno razdoblje i za njegova trajanja visina potpore ograničava se na visinu gornje granice regionalne potpore

Restrukturiranje industrije čelika mora završiti do 31. I2. 2006.

Pretvorba neodgovarajuće fiskalne državne potpore za korisnika u proizvodnji cestovnih vozila u regionalnu potporu za ulaganja; potpora se ograničava na razinu koja odgovara Slovačka iznosu od najviše 30\% prihvatljivih troškova ulaganja.

Obustavljanje neodgovarajuće državne potpore za jednog korisnika iz sektora čelika na kraju 20o9. ili kad potpora dosegne otprije utvrđeni iznos, ovisno o tome koji se uvjet prije ispuni.

Razina državnih potpora smanjena je s 2,8\% BDP-a (2004.) na 1,9\% BDP-a (2007.) Došlo je i do smanjenja udjela sektorskih potpora s 6I\% (2003.) na 54\% (2007.).

Razina državnih potpora smanjena je s 3,7\% BDP-a (2004.) na 2,4\% BDP-a (2007.) Došlo je i do smanjenja udjela sektorskih potpora s 94\% (2004.) na 77\% (2009.).

Razina državnih potpora smanjena je s I,4\% BDP-a (2004.) na o,6\% BDP-a (2007.) Došlo je i do smanjenja udjela sektorskih potpora sa $75 \%$ (2004.) na $14 \%$ (2007.).

Razina državnih potpora smanjena je s o,6\% BDP-a (2004.) na o,4\% BDP-a (2007.) Došlo je i do smanjenja udjela sektorskih potpora s $28 \%$ (2003.) na IO\% (2009.).

Izvor: European Commission (2003)

\section{HETEROGENOST POTPORA KAO REZULTAT RAZLIČITIH POLITIKA}

Kao što prikazuje tablica 3, s obzirom na ukupnu razinu državnih potpora i njihovu namjenu, mogu se identificirati tri podgrupe EUı2 zemalja sličnih politika državnih potpora. Ovisno o kombinaciji razine potpora i udjelu horizontalnih potpora u ukupnim potporama, mogu se identificirati četiri vrste politika državnih potpora, no u praksi se mogu identificirati zemlje za samo tri podgrupe.

Neke EUı2 zemlje poput Estonije (ali i Latvije i Litve) nisu ni prije pristupanja EU-u odvajale značajnija sredstva za državne potpore, a ako i jesu radilo se uglavnom o horizontalnim potporama. U tim zemljama nije došlo do velikih promjena u politici državnih potpora niti neposredno nakon pristupanja niti tijekom posljednjih nekoliko godina.
Tablica 3.

Vrste politika državnih potpora

\begin{tabular}{|c|c|c|c|}
\hline & & \multicolumn{2}{|c|}{ Razina državnih potpora } \\
\hline & & niska & visoka \\
\hline \multirow{2}{*}{$\begin{array}{l}\text { udio } \\
\text { horizontalnih } \\
\text { potpora }\end{array}$} & visok & $\begin{array}{l}\text { Estonija, Češka } \\
\text { (poslije) }\end{array}$ & Slovenija \\
\hline & nizak & - & Poljska, Češka (prije) \\
\hline
\end{tabular}

Izvor: Blauberger (2007)

Drugu skupinu čine zemlje koje su državne potpore koristile $u$ nešto većoj mjeri od prve grupe, ali još uvijek ponajviše za horizontalne ciljeve. Tu spadaju Slovenija i Slovačka pa ni kod njih ne bilježimo značajnije promjene niti u razini državnih potpora niti u promjeni strukture.

U trećoj su skupini zemlje kod kojih je razina državnih potpora bila visoka i uglavnom sektorski usmjerena, a to 
su Poljska, Mađarska, Malta i Cipar. Pregovori s ovim zemljama stoga su rezultirali nizom već spomenutih prijelaznih odredbi. Ta je skupina doživjela najveće fundamentalne promjene i što se tiče razine i strukture potpora, no i unutar nje se uočavaju heterogena kretanja.
Premda je pristupanje vidljivo utjecalo na smanjenje ukupne razine državnih potpora ali i na povećanje udjela horizontalnih potpora, zemlje su u odnosu na ta dva pokazatelja još uvijek ostale relativno heterogene iako u "užem” rasponu njihova kretanja.

\section{Grafikon 6.}

EUI2 grupirane prema politikama državnih potpora (bez prometa i poljoprivrede) prije pristupanja EU-u (prosjek 2000-04., za Bugarsku i Rumunjsku 2002-06.)

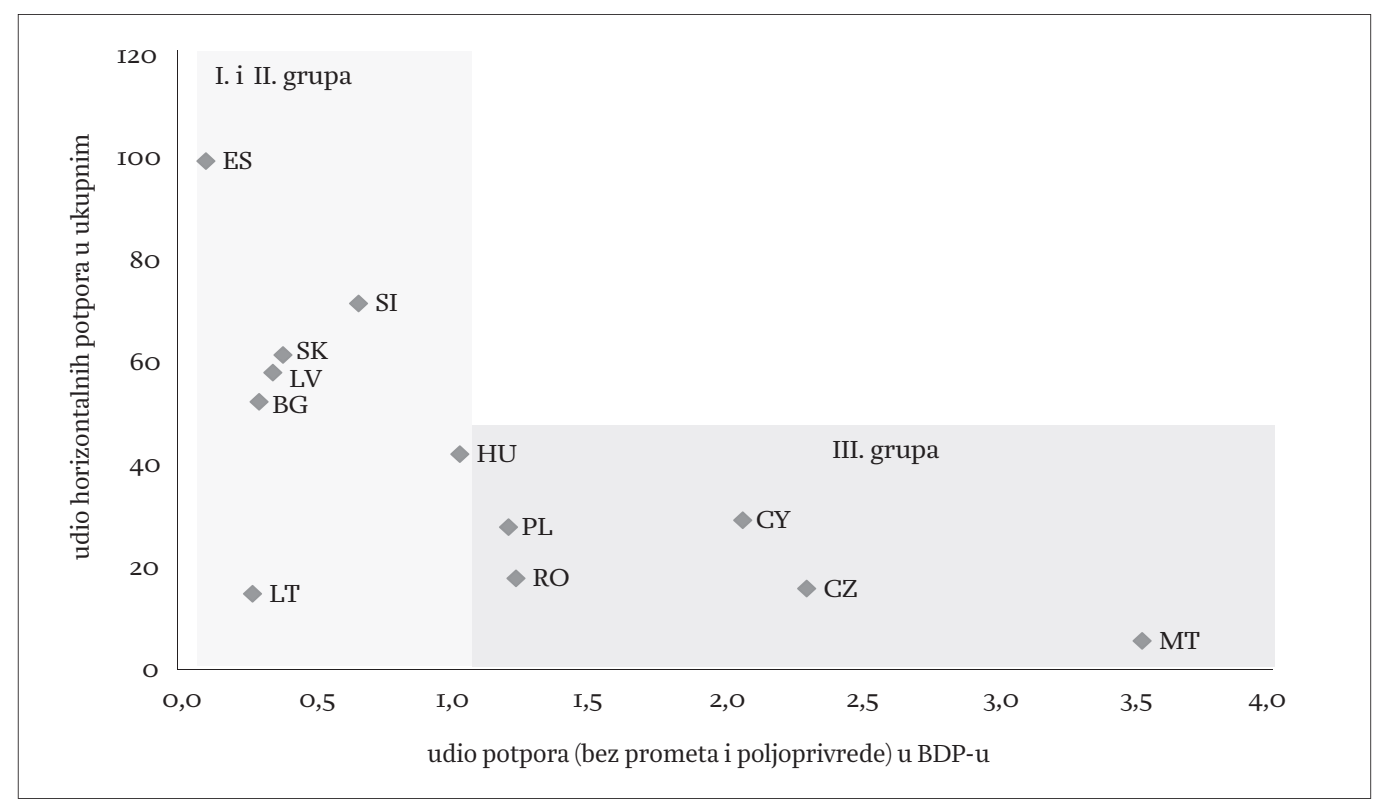

Izvor: European Commission (2012); izračun autorice

\section{Grafikon 7.}

EUI2 zemlje grupirane prema politikama državnih potpora (bez prometa i poljoprivrede) poslije pristupanja EU-u (prosjek 2005-IO., za Bugarsku i Rumunjsku 2007-Io.)

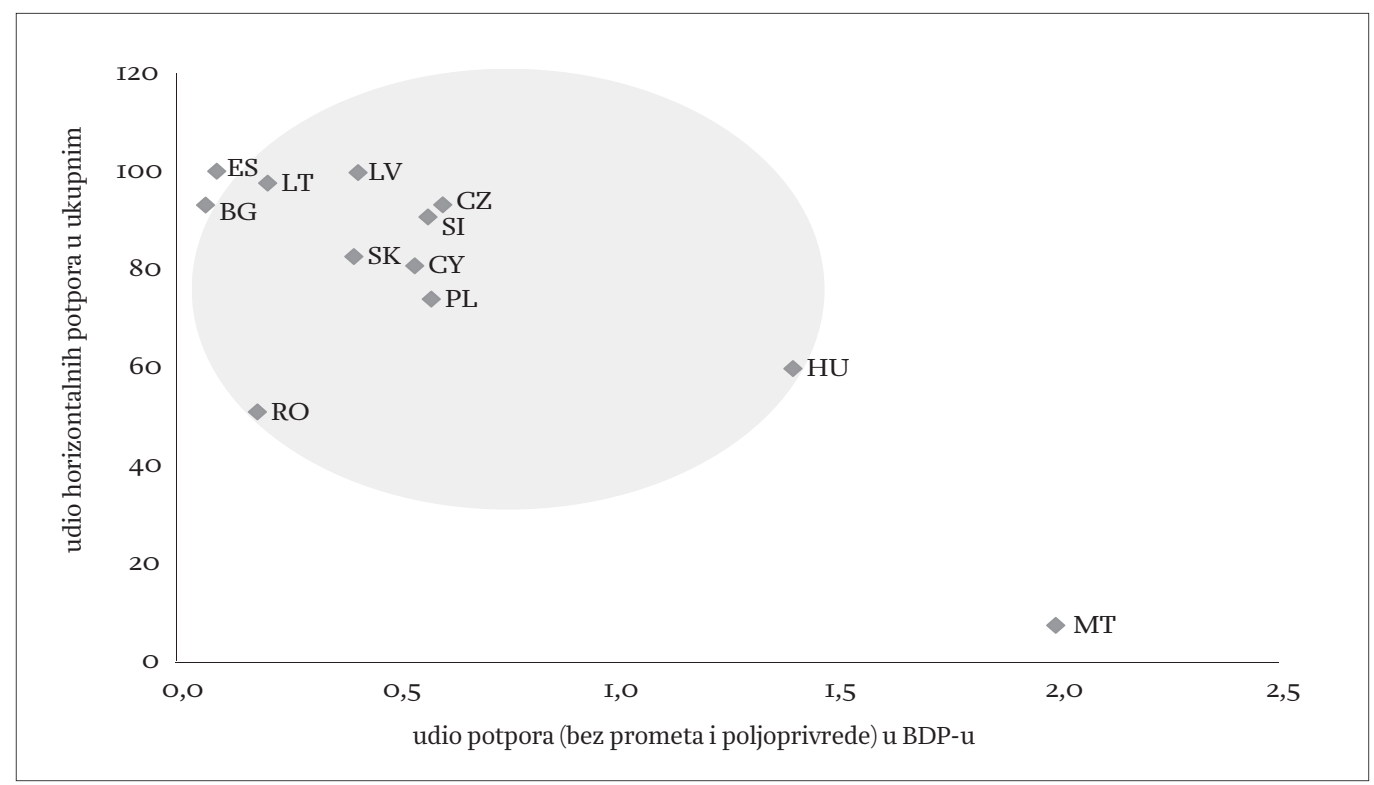

Izvor: European Commission (2012); izračun autorice 


\section{REFORMA DRŽAVNIH POTPORA U EUROPSKOJ UNIJI}

Strategija Europa 2020 prepoznaje važnost državnih potpora i njihovu mogućnost da aktivno i pozitivno pridonesu ciljevima strategije poticanjem i podržavanjem inicijativa koje će omogućiti inovativnije, djelotvornije i "zelenije” tehnologije kroz olakšani pristup državnim potporama za investicije, rizičnom kapitalu te financiranju istraživanja i razvoja.

Modernizacija kontrole državnih potpora treba olakšati ocjenu dobro osmišljenih potpora, usmjerenih na identificirane tržišne neuspjehe i ciljeve od općeg interesa te potpore koje najmanje narušavaju tržišno natjecanje ("dobre potpore"). Reforma kontrole državnih potpora neophodna je kako bi se unaprijedila učinkovitost i djelotvornost javne potrošnje kroz državne potpore, s krajnjim ciljem poticanja rasta zajedničkog tržišta, a za što je neophodan uvjet razvijena konkurencija. Državne potpore koje ne ciljaju tržišne neuspjehe i koje nemaju poticajni učinak nisu samo rasipanje javnih resursa već djeluju i kao kočnica rastu, pogoršavajući konkurentske uvjete na tržištu.

Naglašavajući kvalitetu i učinkovitost državnih potpora, modernizacija kontrole će - kvalitetnijim korištenjem novca poreznih obveznika - pomoći državama članicama u poboljšanju proračunske discipline i unapređenju kvalitete javnih financija. To je posebno važno kako bi se postigla dobra fiskalna konsolidacija koja povezuje ulogu ciljanih javnih rashoda u poticanju rasta s potrebom kontrole proračunskih rashoda.

Ciljevi modernizacije kontrole državnih potpora stoga su trostruki: (I) poticati održivi, pametni i inkluzivni rast konkurentnog unutarnjeg tržišta; (2) usmjeriti ex ante pažnju Europske komisije na slučajeve s najvećim utjecajem na unutarnje tržište te osnažiti suradnju zemalja članica na području državnih potpora; (3) pojednostavniti pravila i omogućiti brže donošenje odluka.

Kontrola državnih potpora tako bi podržavala održivi rast i poboljšala kvalitetu javne potrošnje, obeshrabrujući potpore koje ne donose realnu dodanu vrijednost i narušavaju konkurenciju. U skladu s navedenim ciljevima reforme, Europska komisija razvija zajednička načela za ocjenu sukladnosti nacionalnih državnih potpora te će revidirati i pojednostavniti neke postojeće propise poput Smjernica za zaštitu okoliša, Smjernica za regionalne potpore i Smjernica rizičnog kapitala, ali i Smjernice za sanaciju i restrukturiranje poduzetnika.

U procesu modernizacije Komisija je nedavno objavila nacrt Uredbe o potporama male vrijednosti (de minimis potpore) kojom se gornja granica povećava sa Ioo na 200 tisuća eura te se potpore do tog iznosa ne moraju prijaviti
Europskoj komisiji. Nakon javnih konzultacija nova bi Uredba na snagu trebala stupiti krajem 20I3. što je i planirani datum početka primjene svih uredbi koje će se mijenjati u procesu modernizacije državnih potpora.

\section{LITERATURA:}

Blauberger, M., 2007. European State Aid Control in the New Member States - The Examples of Poland and the Czech Republic. Bremen: University of Bremen, Jean Monet Centre for European Studies.

European Commission, 2003. The Treaty of Accession 2003. Dostupno na: [http://ec.europa.eu/enlargement/ archives/enlargement_process/future_prospects/negotiations/euIo_bulgaria_romania/treaty_2003/content/index_en.htm].

European Commission, 2004. State Aid Scoreboard autumn 2004 update. Brussels, I6. II. 2004. COM (2004)750 final. Dostupno na: [http://ec.europa.eu/ competition/state_aid/studies_reports/archive/2004_ autumn_en.pdf].

European Commission, 2005. State Aid Scoreboard autumn 2005 update. Brussels, 9. 12. 2005. COM (2005)624 final. Dostupno na: [http://ec.europa.eu/ competition/state_aid/studies_reports/archive/2005_ autumn_en.pdf].

European Commission, 2006. State Aid Scoreboard autumn 2006 update. Brussels, II. I2. 2006. $\operatorname{COM}(2006) 76 \mathrm{I}$ final. Dostupno na: [http://ec.europa. eu/competition/state_aid/studies_reports/archive/2006_autumn_en.pdf].

European Commission, 2007. State Aid Scoreboard autumn 2007 update. Brussels, 3I. I2. 2007. COM (2007)79I final. Dostupno na: [http://ec.europa.eu/competition/state_aid/studies_reports/archive/2007_autumn_en.pdf].

European Commission, 2008. State Aid Scoreboard autumn 2008 update. Brussels, I7. II. 2008. COM (2008)75I final. Dostupno na: [http://ec.europa.eu/competition/state_aid/studies_reports/archive/2008_autumn_en.pdf].

European Commission, 2009. Facts and figures on State aid in the EU Member States", Commission Staff Working Document. Brussels 7. 12. 2009. SEC(2009) 1638. Dostupno na: [http://ec.europa.eu/competition/state_aid/ studies_reports/archive/annex_2009_autumn_en.pdf].

European Commission, 2010. Facts and figures on State aid in the EU Member States. Commission Staff Working Document. Brussels I. I2. 20IO. SEC(2010) I462. Dostupno na: [http://eur-lex.europa.eu/LexUriServ/LexUriServ.do?uri=SEC:2OIO:I462:FIN:EN:PDF].

European Commission, 2012. Scoreboard - Data on state aid expenditure. Dostupno na: [http://ec.europa.eu/ 
competition/state_aid/studies_reports/expenditure. html].

European Commission, 20I2b. State Aid Modernisation. Dostupno na: [http://ec.europa.eu/competition/state_aid/modernisation/index_en.html].

Kesner-Škreb, M., 2012. "Što će biti s hrvatskim državnim potporama nakon pristupanja Europskoj uniji”. New- sletter, br. 70. Dostupno na: [http://www.ijf.hr/upload/files/file/newsletter/7o.pdf].

Mulas-Granados, G., Koranchelian, T. i SeguraUbiergo, A., 2008. "Reforming Government Subsidies in the New Member States of the European Union”. IMF Working paper, WP/O8/165. Washington: International Monetary Fund. 